\title{
Thunbergia kasajuana, a new species of Acanthaceae from Nepal
}

\author{
Bhaskar Adhikari ${ }^{1}$ \& John R. I. Wood ${ }^{2,3}$ (D)
}

Summary. A new species of Thunbergia, T. kasajuana Bh.Adhikari \& J.R.I.Wood is described from central Nepal. It is most closely related to T. grandiflora Roxb., because of its reduced annular calyx and similar inflorescence structure but differs in the much smaller corolla, herbaceous habit and different ecology. A description, photographs and a key to the species of Thunbergia native to Nepal are provided.

Key Words. endemism, Himalaya, taxonomy.

\section{Introduction}

The genus Thunbergia Retz. comprises around 100 150 species (Borg et al. 2008; Vollesen 2008; Mabberley 2017) distributed through the tropical and subtropical regions of the Old World. It consists of erect or twining plants, although the native species of the Himalayas are all twiners. It is characterised by the presence of two large bracteoles enclosing the calyx and part of corolla tube, the reduced annular rim-like or shortly toothed calyx, and a woody capsule with a prominent beak. Several species are cultivated in tropical and temperate regions of the world because of their showy flowers, including T. laurifolia Lindl., which appears to be closely related to $T$. grandiflora Roxb. but is so far unrecorded from Nepal, T. alata Bojer ex Sims and T. erecta (Benth.) T. Anderson, both of which are known to be cultivated in Nepal. The only native species cultivated as an ornamental is T. coccinea Wall. ex D.Don.

The main centre of diversity of the genus is south and east Africa, 49 species being recorded in the Flora of Tropical East Africa (Vollesen 2008). It is less diverse in Asia with around 35 species recorded from SE Asia (Bremekamp 1955), 13 species (10 native) from India (Karthikeyan et al. 2009), six from China (Hu et al. 2011), five from Bhutan (Wood 2001) and 14 from Myanmar (Kress et al. 2003) of which 11 are native.

The five recognised native species from Nepal were described, discussed and illustrated by Adhikari et al. (2013). The commonest species is the very distinctive red-flowered Thunbergia coccinea (Fig. 1F) which is widely distributed in tropical and subtropical forest from 100 - $2100 \mathrm{~m}$ throughout Nepal. Thunbergia fragrans Roxb. (Fig. 1A, B), and T. grandiflora (Fig. 1D, E) are both commonly found in Tarai forest, and on the lower slopes of the Himalayas in central and eastern Nepal. Thunbergia lutea T.Anderson is rare and known from only two localities in eastern Nepal but is easily distinguished from other species found in Nepal by its pinnately veined leaves. Thunbergia nepalensis Bh.Adhikari \& J.R.I.Wood (Fig. 1C) is found at around $2100 \mathrm{~m}$ in two locations in western Nepal and is distinguished by its 5 - 7-toothed calyx, the teeth ovate-deltoid in shape. The discovery of T. kasajuana Bh.Adhikari \& J.R.I.Wood by Saroj Kasaju in the Nagarkot region of central Nepal brings the total number of native Thunbergia species known from Nepal to six.

The most recent infrageneric classification of the genus by Bremekamp (1955) recognised seven subgenera to which one was added by Vollesen (2008). These subgenera are partially supported by molecular studies (Borg et al. 2008). The new species appears to belong to subgen. Hexacentris Benth. \& Hook.f. emend. Bremek. to which T. grandifolia and $T$. coccinea also belong. It is a monophyletic, "rather well-defined group of woody climbers" (Borg et al. 2008) which can be recognised morphologically by its annular calyx and eglandular corolla.

\section{Materials and Methods}

This paper is based on field studies by the first author in Nepal and by studies of specimens and literature by both authors. Specimens of Thunbergia, including the types, were examined at BM, E, K and KATH herbaria (herbarium codes follow Thiers, 2016 onwards). Published literature on the genus Thunbergia (Bremekamp 1955; Wood 2001; Vollesen 2008; Karthikeyan et al. 2009; Hu et al. 2011; Adhikari et al.

\footnotetext{
Accepted for publication 4 March 2020. Published online 15 May 2020

1 Royal Botanic Garden Edinburgh, Scotland, EH3 5LR, UK.

2 Honorary Research Associate, Royal Botanic Garden Kew, Richmond, Surrey, TW9 3AB, UK. e-mail: jriwood@hotmail.com

3 Department of Plant Sciences, University of Oxford, Oxford, OX1 3RB, UK.
} 

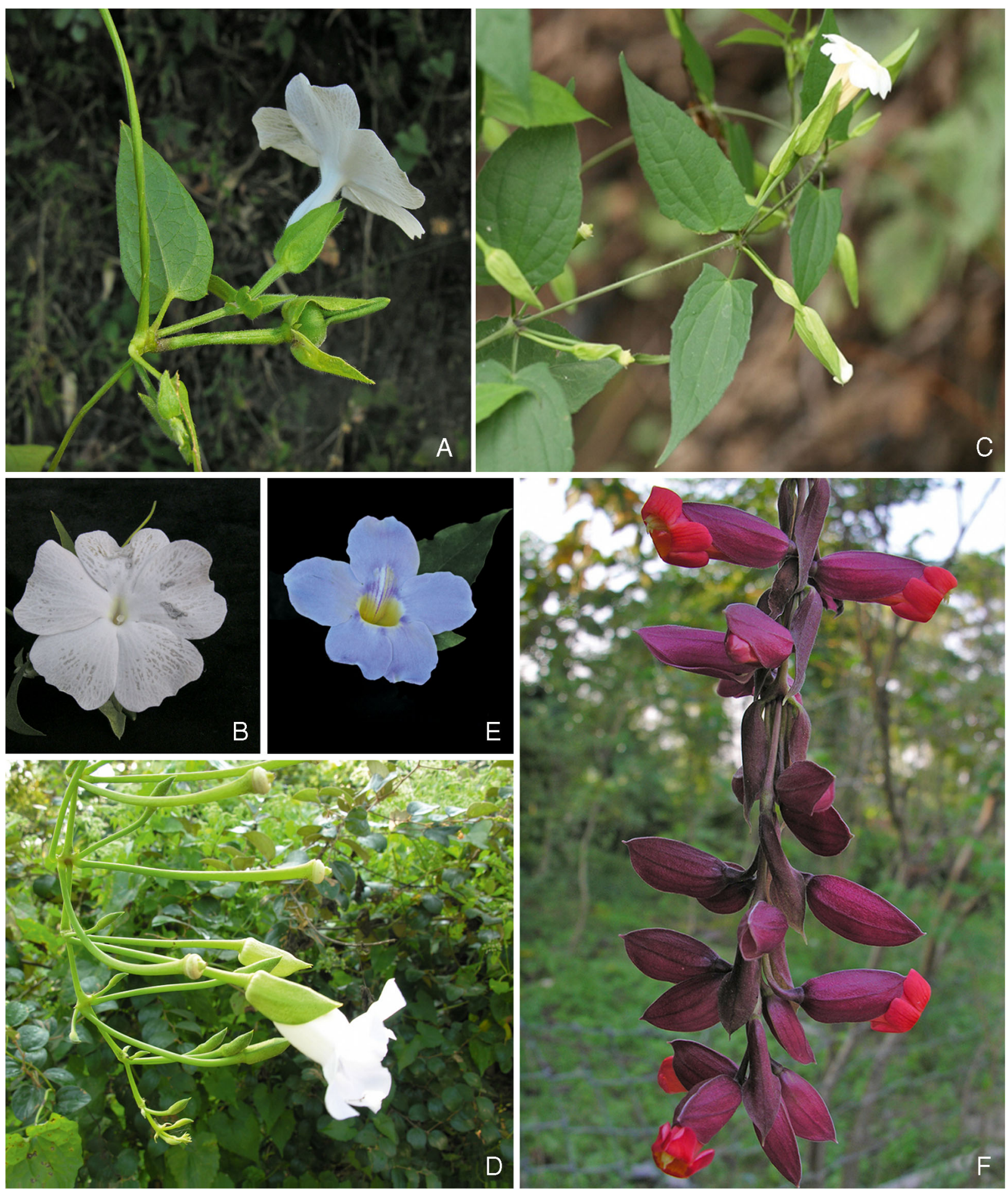

E
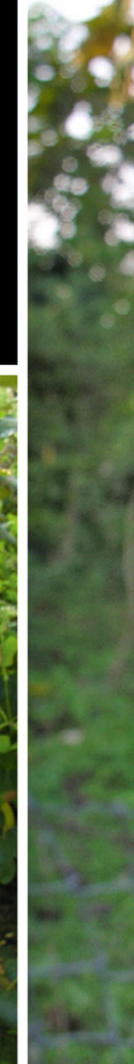

Fig. 1. Selected species of Thunbergia found in Nepal. A, B T. fragrans; C T. nepalensis; D, E T. grandiflora; F T. coccinea. PHotos: A, B, D - F BHASKAR ADHIKARI; C H. IKEDA.

2013) was also checked. The specimens and photographs of the new species were compared with all known species of Thunbergia from adjacent regions. Particular attention was paid to species recorded from north east India and Myanmar, those from South
India pertaining to a different phytogeographical region. Of those listed by Karthikeyan et al. 2009, only two from northern India were unknown in Nepal and both of these, T. leavis Nees and T. maculata Lace were clearly related to $T$. fragrans and thus belonged to a 
different subgenus of Thunbergia. Search through the Myanmar checklist (Kress et al. 2003) revealed two possible species said by their authors (Gamble 1913; W. W. Smith 2014) to belong to subgen. Hexacentris, although both were recorded far to the east of Nepal. Both are represented in the Kew herbarium; T. lacei Gamble has a dentate calyx so can be excluded from consideration; T. papilionacea W.W.Sm. appears to be correctly placed in subgen. Hexacentris but differs from T. kasajuana in its subtomentose indumentum, densely hirsute ovary and presumed purple flowers.

The following key is a modified version of that provided by Adhikari et al. (2013) with the addition of the new species.

\section{Key to native species of Thunbergia found in Nepal}

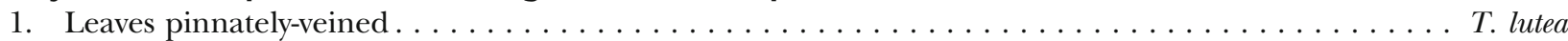

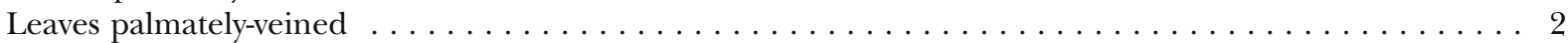

2. Corolla red or orange-red, flowers in many-flowered, long-pendulous, axillary or terminal racemes up to $45 \mathrm{~cm}$

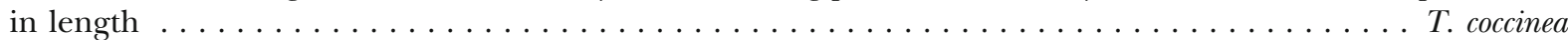
Corolla white, bluish-white or yellowish white, flowers solitary or paired in the leaf axils and sometimes also in

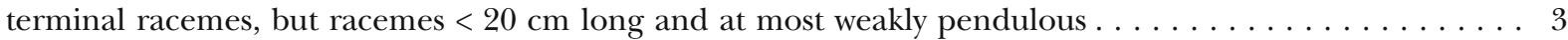

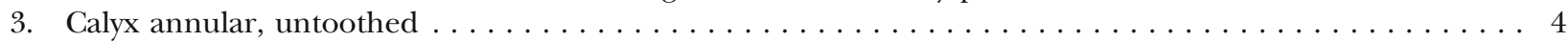

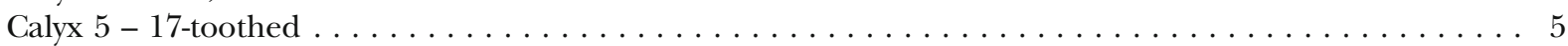

4. Woody climber; corolla lobes $2.5-4 \times 2-2.5 \mathrm{~cm} \ldots \ldots \ldots \ldots \ldots \ldots \ldots \ldots \ldots \ldots \ldots \ldots \ldots$ grandiflora Herbaceous climber, corolla lobes $0.5-0.8 \times 0.5-1 \mathrm{~cm} \ldots \ldots \ldots \ldots \ldots \ldots \ldots$. . kasajuana

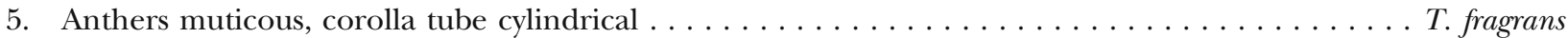
Anthers spurred, corolla tube gradually widened from base ................. T. nepalensis

\section{Taxonomic Treatment}

Thunbergia kasajuana Bh.Adhikari E J.R.I.Wood, sp. nov. Type: Nepal, Bhaktapur, Nagarkot, 2020 m, 6 Sept. 2018, S. Kasaju 133 (holotype KATH; isotype E).

http:/ /www.ipni.org/urn:lsid:ipni.org:names:77206325-1

Herbaceous climber to $4 \mathrm{~m}$. Stem angular, sulcate, hirsute, more densely so towards the nodes. Leaves petiolate, ovate or ovate-triangular, $5-9 \times 3.5-6.5 \mathrm{~cm}$, base cordate to hastate, apex acuminate, margin irregularly and shallowly dentate, palmately 5 - 7-veined, both surfaces sparsely strigose, more densely so towards the margin and veins; petioles $2-5 \mathrm{~cm}$ long. Flowers solitary in the leaf axils or in the axils of bracts, often aggregated into terminal racemes, racemes $3-12 \mathrm{~cm}$ long, pedicels $1-1.5 \mathrm{~cm}$; bracts small, ovate, $5-10 \times 2$ - $4 \mathrm{~mm}$, minutely pubescent; bracteoles green, ovate, $1.5-2 \times 1-1.5 \mathrm{~cm}$, apex mucronate, minutely pubescent, the pubescence denser at the margins; calyx annular, unlobed, $1.5-2 \mathrm{~mm}$ long in flower, accrescent to $3 \mathrm{~mm}$ in fruit; corolla white, the throat yellowish with pinkish veins, glabrous internally and externally, tube $2.5-3.5 \mathrm{~cm}$, constricted at base for c. $0.5 \mathrm{~cm}$ then gradually widened to $1 \mathrm{~cm}$ at mouth, lobes obovate to rounded, $0.5-0.8 \times 0.5-1 \mathrm{~cm}$; filaments slightly unequal, shorter $8-10 \mathrm{~mm}$, longer 9 - $12 \mathrm{~mm}$, anthers bearded, spurred, the spur $2-3$ $\mathrm{mm}$, finely acuminate; ovary glabrous, style $2.5-3 \mathrm{~cm}$, stigma bilobed, lobes subequal, upper folded inwards, lower spreading. Capsule glabrous or minutely pubescent, basal part $1-1.5 \mathrm{~cm}$ wide, beak $2-2.5 \mathrm{~cm}$ long; seeds $5-7$ mm. Fig. 2.
RECOGNITION. Among Nepal species Thunbergia kasajuana is most similar to $T$. grandiflora in its inflorescence and calyx. In both $T$. grandiflora and T. kasajuana the calyx is annular and untoothed but T. grandflora is a woody climber and has much larger corolla lobes $(2.5-4 \mathrm{~cm}$ long, not $0.5-0.8 \mathrm{~cm}$ long as in T. kasajuana). Moreover, T. grandiflora is a lowland species with pale blue or whitish flowers found below $1300 \mathrm{~m}$ while T. kasajuana has pink tinged flowers and is found at around $2000 \mathrm{~m}$.

Thunbergia kasajuana bears a superficial resemblance to $T$. nepalensis but is readily distinguished by its annular, untoothed calyx (5 - 7-toothed in T. nepalensis). Table 1.

DISTRIBUTION. Endemic to central Nepal.

SPECIMENS EXAMINED. NEPAL. Bhaktapur Distr., Nagarkot, 2020 m, fr., 12 Dec 2017, S. Kasaju 1010 (KATH); Bhaktapur Distr., Nagarkot, 2020 m, fl., 21 Aug. 2018, S. Kasaju 120 (KATH); Bhaktapur Distr., Nagarkot, 2020 m, fr. 23 Sept. 2018, B. Adhikari $\mathcal{E} S$. Kasaju 111 (E, KATH); Bhaktapur, Nagarkot, 2020 m, 6 Sept. 2018, S. Kasaju 133 (holotype KATH; isotype E).

HABITAT. Mixed forest on south-west facing slopes in association with Clematis montana D.Don (Ranunculaceae), Eriobotrya japonica (Thunb.) Lindl. (Rosaceae), Lindera pulcherrima (Nees) Benth. ex Hook.f., (Lauraceae), Myrica esculenta Buch.-Ham. ex D. Don (Myricaceae), Prunus cerasoides D.Don (Rosaceae), Pyrus pashia Buch.-Ham. ex D.Don (Rosaceae), Rhododendron arboreum $\mathrm{Sm}$. (Ericaceae), Rubus sp. (Rosaceae), Symplocus sp. (Symplocaceae) etc.

CONSERVATION STATUS. Thunbergia kasajuana is known from only $3-4$ individuals in one population in 

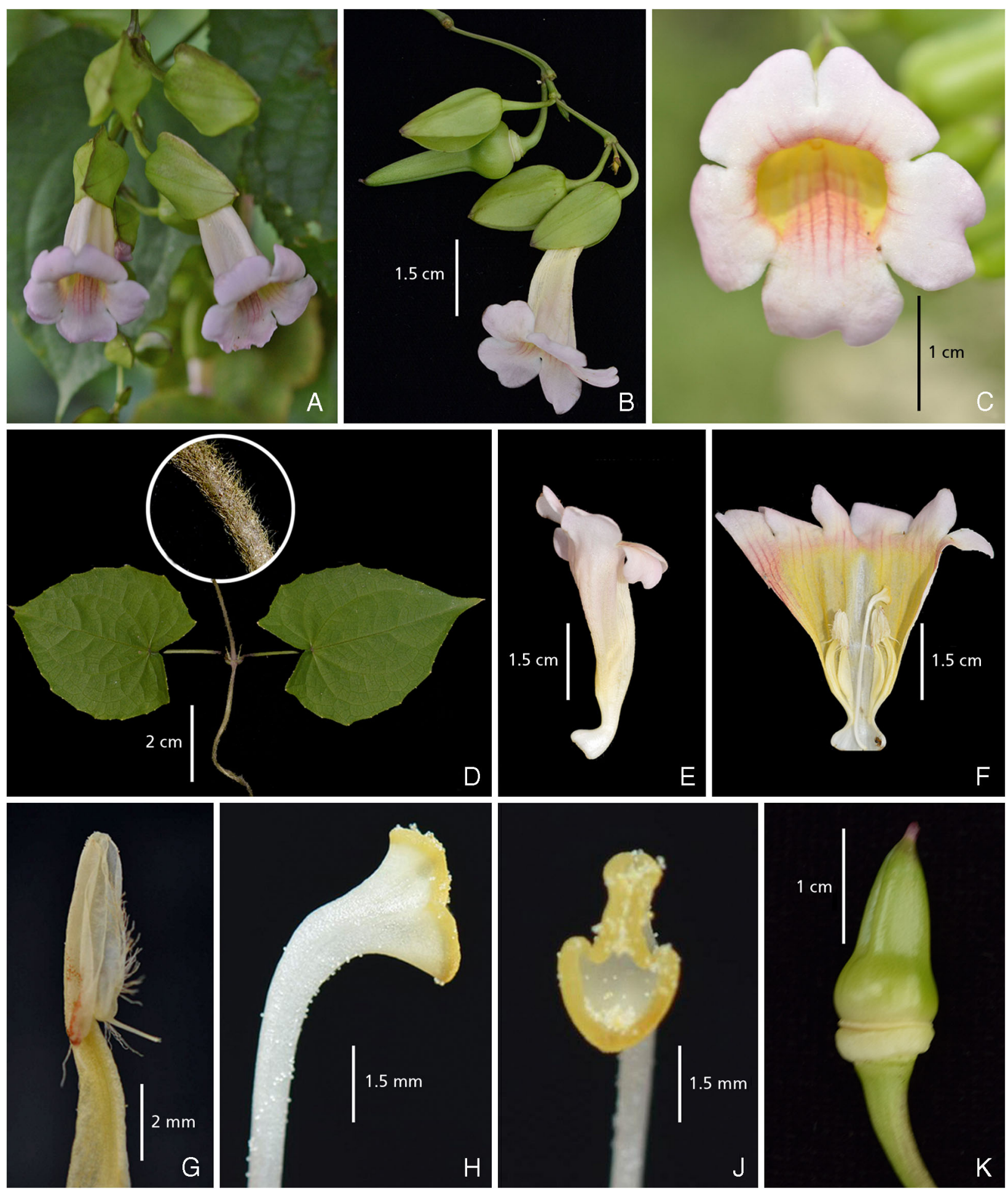

Fig. 2. Thunbergia kasajuana. A flowering branch; B flowering branch showing young capsule and bracteoles; C corolla, front view; D branch with leaves and inset of stem; E corolla, side view; F corolla opened out to show stamens and style; $G$ filament; $H$ style showing stigma (side view); J stigma (front view); K young fruit. PHOTOS: A - J SAROJ KASAJU; K BHASKAR ADHIKARI.

Bhaktapur district of Central Nepal. More extensive collections from similar habitats from subtropical and temperate regions of Nepal will be needed to confirm its conservation status but the forest where it is found is reported to be still in good condition. Saroj Kasaju also reports having seen it on Shivapuri Hill near Kathmandu, but no specimens have been seen. It is accordingly categorised as Data Deficient according to the IUCN 
Table 1. Characters differentiating Thunbergia kasajuana, T. nepalensis, T. grandiflora and T. fragrans

\begin{tabular}{lllll}
\hline \hline Character & \multicolumn{1}{c}{ T. kasajuana } & \multicolumn{1}{c}{ T. nepalensis } & \multicolumn{1}{c}{ T. grandiflora } & T. fragrans \\
\hline Habit & herbaceous twiner & herbaceous twiner & vigorous woody climber & herbaceous twiner \\
Calyx & annular & irregularly $5-7$ toothed & annular & finely $12-16$ toothed \\
Corolla lobes $(\mathrm{cm})$ & $0.5-0.8 \times 0.5-1$ & $1-1.5 \times 0.8-1$ & $2.5-4 \times 2-2.5$ & $1-2 \times 1.5-2$ \\
Anthers & spurred & spurred & spurred & muticous \\
Stigma & bilobed, upper folded, & bilobed, lobes subequal & bilobed, lobes subequal & unlobed \\
& $\quad$ lower spreading & c. 2100 & $200-1300$ & $200-2000$ \\
Altitude range $(\mathrm{m})$ & c. 2000 & & & \\
\hline
\end{tabular}

Red List of Threatened Species (IUCN 2012), until more information about its distribution and the status of its population becomes available.

PHENOLOGY. This species flowers in August and September at the end of the wet monsoon season and has been found in fruit in September and December.

ETYMOLOGY. The specific epithet kasajuana honours Mr Saroj Kumar Kasaju, who first discovered and photographed the species. Mr Kasaju is a citizen scientist contributing to our understanding of the flora of Nepal by taking photos of plant species from Nepal and India. He was actively involved in the identification of this species.

\section{Acknowledgements}

We would like to thank the curators of BM, E, K and KATH for providing access to their herbarium collections and to Saroj Kumar Kasaju for his photographs and specimens. The Royal Botanic Garden Edinburgh is supported by the Scottish Government's Rural and Environment Science and Analytical Services Division.

Open Access This article is licensed under a Creative Commons Attribution 4.0 International License, which permits use, sharing, adaptation, distribution and reproduction in any medium or format, as long as you give appropriate credit to the original author(s) and the source, provide a link to the Creative Commons licence, and indicate if changes were made. The images or other third party material in this article are included in the article's Creative Commons licence, unless indicated otherwise in a credit line to the material. If material is not included in the article's Creative Commons licence and your intended use is not permitted by statutory regulation or exceeds the permitted use, you will need to obtain permission directly from the copyright holder. To view a copy of this licence, visit http://creativecommons.org/licenses/by/4.0/.

\section{References}

Adhikari, B., Pendry, C. A., Watson, M. F. \& Wood, J. R. I. (2013). An account of Thunbergia (Acanthaceae) in Nepal, with a description of the new species T. nepalensis. Kew Bull. 68: 651 - 661.
Borg, A. J., McDade, L. \& Schönenberger, J. (2008). Molecular phylogenetics and morphological evolution of Thunbergioideae (Acanthaceae). Taxon 57: $811-822$.

Bremekamp, C. E. B. (1955). The Thunbergia species of the Malesian area. Verh. Kon. Ned. Akad. Wetensch., Afd. Natuurk., Sect. 2: 50 (4): 1 - 90.

Gamble, J. G. (1913). No. 716. Thunbergia lacei. In: Decades Kewenses 16. Bull. Misc. Inform., Kew 1913: 113 - 118.

Hu, J. Q., Deng, Y. F. \& Daniel T. F. (2011). Thunbergia. In: Z. Y. Wu, P. F. Raven \& D. Y. Hong (eds), Flora of China 19: 377 - 379. Science Press, Beijing \& Missouri Botanical Garden Press, St Louis.

IUCN (2012). Guidelines for application of IUCN Red List Criteria at Regional and National Levels. International Union for the Conservation of Nature, Cambridge \& Gland.

Karthikeyan, S., Sanjappa, M. \& Moorthy, S. (2009). Flowering Plants of India: Dicotyledons. Vol. 1. (Acanthaceae Avicenniaceae). Botanical Survey of India.

Kress, W. J., DeFilipps, R. A., Farr, E. \& Kyi, D. Y. Y. (2003). A checklist of the trees, shrubs, herbs and climbers of Myanmar. Contr. U.S. Natl. Herb. 45: 1- 590.

Mabberley, D. J. (2017). Mabberley's Plant-Book, 4th ed. Cambridge University Press, Cambridge.

Smith, W. W. (2014). Species Novae Plantarum in Herbario Horti Reg. Calcutt. Cognitarum. Rec. Bot. Surv. India 6: 99 - 104.

Thiers, B. (2016 onwards). Index Herbariorum: A Global Directory of Public Herbaria and Associated Staff. New York Botanical Garden's Virtual Herbarium. http://sweetgum.nybg.org/science/ih/.

Vollesen, K. (2008). Acanthaceae (Part 1). In: H. J. Beentje \& S. A. Ghazanfar (eds), Flora of Tropical East Africa. Royal Botanic Gardens, Kew.

Wood, J. R. I. (2001). Acanthaceae. In: A. J. C. Grierson \& D. G. Long (eds), Flora of Bhutan 2 (3): 1243 - 1293. Royal Botanic Garden, Edinburgh \& Royal Government of Bhutan.

\section{Publisher's Note}

Springer Nature remains neutral with regard to jurisdictional claims in published maps and institutional affiliations. 